\title{
Antimicrobial Activity of Cell Free Supernatant of Lactic Acid Bacteria Isolated from Fermented Durian Flesh against Multiple Antibiotic Resistance's Salmonella Associated with Food Poisoning Cases in Malaysia
}

\author{
Fajriah Salleh $^{1,2}$, Mohd Nizam Lani ${ }^{1}$, Noraznawati Ismail ${ }^{3}$ \\ ${ }^{I}$ School of Food Science and Technology, Universiti Malaysia Terengganu (UMT), 21030 Kuala \\ Terengganu, Terengganu, Malaysia \\ ${ }^{2}$ Terengganu Health Department, Food Safety and Quality Laboratory, d/a Klinik Kesihatan Bukit \\ Tunggal, 21200 Kampung Bukit Tunggal, Terengganu, Malaysia, \\ ${ }^{3}$ Institute of Marine Biotechnology, Universiti Malaysia Terengganu (UMT), 21030 Kuala \\ Terengganu, Terengganu, Malaysia
}

\begin{abstract}
Epidemic of food poisoning cases and outbreaks associated with Salmonella spp. have been increased all over the world. Most of food poisoning cases in Malaysia related to Salmonella are associated with contaminated water compared to other sources. Finding alternative treatment to reduce foodborne cases becomes crucial, and bio-preservation using lactic acid bacteria $(L A B)$ is one of strategy that can be used in food industries. The objective of this study was to determine the antimicrobial activities in vitro of cell free supernatant from eight LAB strains isolated from fermented durian flesh, which were 5 strains from Lactobacillus buchneri, 1 strain from each culture, Lactobacillus plantarum, Lactobacillus brevis 1 and Lactobacillus acidophilus 1 against 23 species of various serotypes of pathogenic Salmonella obtained from food poisoning cases in Malaysia. The antimicrobial activity of crude bacteriocins from cell free supernatant (CFS) of LAB strains were tested using well diffusion method. Susceptibility test of eight selected Salmonella strains was done using disk diffusion method (DDT) against twelve selected antibiotics. Results showed that crude bacteriocins of Lb. plantarum, Lb. buchneri, Lb. brevis 1 and Lb. acidophilus 1 from fermented durian flesh had strong inhibitory effect against most of 23 species of MAR's Salmonella associated with food poisoning cases with intermediate to high inhibitory zone by average mean from $16 \mathrm{~mm}$ to $22 \mathrm{~mm}$ diameter zone. All eight Salmonella strains were resistant to bacitracin, nalidixic acid and vancomycin and some strains were also resistant to ampicillin, penicillin, streptomycin and tetracycline. Further study could be utilised to understand the mechanism of selected LAB bacteriocin producer from fermented durian flesh as antimicrobial substance.
\end{abstract}

Keywords: antimicrobial activity, bacteriocin, fermented durian flesh, Lactic Acid Bacteria, Salmonella

\section{Introduction}

Food poisoning and outbreaks associated with Gram negative bacteria such as Salmonella spp. had been increased recently in Malaysia. The genus Salmonella, which belongs to the family of Enterobacteriaceae, is an important foodborne pathogen. There are two species in the genus Salmonella: S. enterica (six subspecies) and $S$. bongori (one subspecies). Members of the seven subspecies can be serotyped into one of more than 2500 different serovars based on somatic $(\mathrm{O})$ and flagellar $(\mathrm{H})$ antigens (Popoff, 2001). Non-typhoidal Salmonella remains the leading cause of bacterial food-borne infections and continue to be a main problem, in terms of both morbidity and economic costs (Modarressi \& Thong, 2010). Salmonella serovars typhimurium and enteritidis are the supreme public source of human salmonellosis globally (Archambault et al., 2006), other Salmonella serovars associated with food poisoning cases are becoming important in recent years.

Malaysia produces several kinds of fermented foods which have been known for their antimicrobial activity. Fermented durian flesh which is also known as 'Tempoyak', is one of the valuable heritage food product that previously had been proven to have a diversity of lactic acid bacteria microflora with superior properties in inhibiting the growth and multiplication of pathogenic bacteria. Fermented durian flesh is a traditional Malaysian fermented condiment made from the pulp of the durian fruit (Durio zibethinus) and indeed is an economically significant fruit in the region of South-East Asia (Leisner et al., 2001). It has a unique durian smell and a creamy yellow colour and is commonly consumed in both Malaysia and Indonesia as side dish and condiment (Battcock and Ali, 1998; Irwandi and Che-Man, 1996).

Numerous kind of Lactic Acid Bacteria (LAB) strains were isolated from fermented durian flesh from all over the South East Asia region. From the past studies, Lactobacillus species have been the predominant LAB microflora in tempoyak produced in Indonesia and Malaysia. However, the type of LAB microflora is 
influenced by the place where the product is prepared (Yuliana \& Dizon, 2011). For example, Lactobacillus plantarum, Lactobacillus brevis, Lactobacillus mali, Lactobacilus fermentum were found in tempoyak from Malaysia (Issa 2000, Leisner et al., 2001), while Wirawati (2002) and Ekowati (1998) isolated Lactobacillus plantarum, Lactobacillus casei, Lactobacillus corynebacterium, and Lactobacillus casei, from tempoyak in Indonesia. It is acknowledged that lactic acid bacteria produce antimicrobial compounds particularly bacteriocins with high antimicrobial activity (Kormin et al., 2001).

The occurrence of Multiple Antibiotic Resistant (MAR) bacterial strain is of public health concern because the bacteria are not easily killed by normal antibiotics used for health therapy (Aween et al., 2012). Previous study by Aween et al., 2012 had demonstrated that both cells and supernatants of LAB isolated from honey samples marketed in Malaysia could inhibit the growth of the MAR's bacteria. Lb. acidophilus supernatant showed bactericidal effect against the MAR target bacteria especially Staphylococcus aureus. However, no study has been reported on the ability of LAB isolated from 'tempoyak' against MAR's bacteria.

Although the use of LAB as probiotics has received well attention, the application of LAB to reduce food poisoning cases is still underexplored. The infection of foodstuff with foodborne and pathogenic bacteria are global issue and it is severe hazard for the health of the human (Muhialdin et.al, 2012). Therefore, the objective of this study was to determine the antimicrobial activities of crude bacteriocins from eight LAB strains isolated from fermented durian flesh, which were five strains from Lactobacillus buchneri, one strain from each culture of Lb. plantarum, Lb. brevis 1 and Lb. acidophilus 1, against Multiple Antibiotic Resistant (MAR)'s Salmonella strains associated with food poisoning cases in Malaysia.

\subsection{Source of Microorganisms}

\section{Materials And Methods}

Salmonella typhimurium ATCC 14028 culture was obtained from Microbiological Unit, Terengganu Food Safety and Quality Control Laboratory, Health Department, Ministry of Health, Malaysia. For food poisoning Salmonella cultures, 23 serotypes of Salmonella strains associated with food poisoning cases and outbreaks were obtained from several laboratories under Food Safety and Quality Division, Ministry of Health, Malaysia.

\subsection{Susceptibility of Salmonella strains towards antibiotics}

Eight selected Salmonella strains were tested for their resistance and susceptibility to selected antibiotics were tested by using disc diffusion method (Harrigan, 1998). Eleven antibiotics used were ampicillin

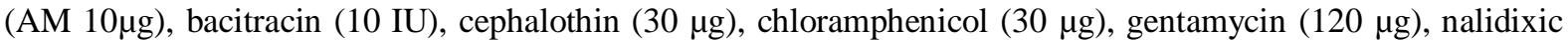
acid $(30 \mu \mathrm{g})$, penicillin $(10 \mathrm{IU})$, polymycin B (300 IU), streptomycin $(10 \mu \mathrm{g})$, tetracycline $(21 \mu \mathrm{g})$ and vancomycin $(30 \mu \mathrm{g})$. These antibiotics were commonly used to treat infection caused by food poisoning cases.

After an overnight incubation at $37^{\circ} \mathrm{C}$, the diameter of each zone of inhibition was measured with a ruler or caliper. In all measurements, the zones of inhibition are measured from the edges of the last visible colony-forming growth. The ruler was positioned across the centre of the disc to make these measurements. The results were recorded in millimetres $(\mathrm{mm})$ and interpretation of susceptibility was obtained by comparing the results to the standard zone sizes. Inhibition zone diameters were measured inclusive of the diameter of the discs. Results were expressed as sensitive, $S(\geq 21 \mathrm{~mm})$; intermediate, I (16-20 mm) and resistant, $\mathrm{R}(\leq 15 \mathrm{~mm})$, respectively according to that described by Vlková et al., (2006).

\subsection{Preparation of Cell Free Supernatant from LAB isolated from fermented durian flesh}

Eight of LAB strains isolated from fermented durian flesh that previously have been identified using phenotypic identification system (API 50 CHL) and other biochemical testes were used in this study (Salleh et al., 2014). Five of these LAB strains were Lb. buchneri, and the rest was each LAB strains from Lb. plantarum, $L b$. brevis 1 and $L$ b. acidophilus 1 . Cell free supernatant from each LAB strain were prepared by centrifugation at $10,000 \mathrm{rpm}$ for 5 minutes after all LAB colonies cells were harvested anaerobically at $30^{\circ} \mathrm{C}$ for $24 \mathrm{~h}$ in MRS (de Man, Rogosa and Sharpe) broth until the cultures reached about $10^{7} \mathrm{CFU} / \mathrm{ml}$. The cell free supernatants were then be used for antimicrobial activity using agar well diffusion assay. The microbiological media was purchased from Merck, Germany.

\subsection{Evaluation of Antimicrobial Activity against Salmonella spp. using Agar Well Diffusion Assay}

Targeted colony of 23 strains of food poisoning Salmonella spp and Salmonella typhimurium ATCC 14028 was diluted using $0.1 \%$ peptone water (PW) to get $0.5 \mathrm{McFarland}$ Turbidity Standard. All targeted gram negative pathogenic bacteria being used were freshly streaked onto Muller Hilton Agar (Merck, Germany) respectively using Kirby Bauer technique. Then, $5 \mathrm{~mm}$ diameter size of well were immediately made up in each plates and $20 \mu \mathrm{l}$ molten agar be poured to each well until solidified. Immediately, $80 \mu \mathrm{l}$ of CFS from each LAB strains were transferred to each well separately. Each plate was controlled by adding with sterilized PW. All 
plates were aerobically incubated at $37^{\circ} \mathrm{C}$ for $24 \mathrm{~h}$. For measurements, the zones of inhibition were measured from the edges of the last visible antimicrobial inhibition growth without deducted with the size of the LAB well (Kirby Bauer). The ruler was positioned across the centre of the well to make these measurements. The pathogenic bacteria without LAB cultures were used as control of experiments. The experiments were conducted twice in order to obtain the average mean of diameter of inhibitory zone.

\section{Results And Discussion}

3.1 Susceptibility of Salmonella strains associated with food poisoning cases in Malaysia towards antibiotics

The occurrence of multiple antibiotic resistant among Salmonella strains associated with food poisoning in Malaysia is summarised in Table 1. These selected strains were found to be resistant to bacitracin, nalidixic acid and vancomycin, while some strains such as $S$. adamstua (fp 021/K) was resistant to ampicillin and $S$. albany (fp $020 / \mathrm{K}$ ) and $S$. adamstua (fp $021 / \mathrm{K}$ ) were resistant to penicillin. At the same time, S. albany (fp 020/K), S. adamstua (fp 021/K) and S. corvalis (fp 02/K) were also resistant to tetracycline. Similarly, Bouchrif et al. (2009) observed that S. typhimurium phage type DT104 is a multiple antibiotic resistant strain to ampicillin, tetracycline, chloramphenicol, sulfamethoxazole and streptomycin. To the best of our knowledge, this is the first report on the occurrence of MAR among Salmonella strains associated with food poisoning cases in Malaysia. This present study highlights that these Salmonella associated with food poisoning cases may easily become multiple antibiotic resistant (MAR).

Table 1: Susceptibility of Salmonella spp. from food poisoning isolates towards antibiotics using disk diffusion test (DDT)

\begin{tabular}{|c|c|c|c|c|c|c|c|c|}
\hline Antibiotics & S.typhimurium & S.enteritidis & S.paratyphi B & S.richmond & S.corvalis & S.albany & S.adamstua & S.corvalis \\
\hline & (fp 001/K) & (fp002/K) & (fp 003/K) & (fp 006/K) & (fp 019/K) & (fp 020/K) & (fp 021/K) & (fp 023/K) \\
\hline Ampicillin (10ug) & 21 & 21 & 22 & 21 & 19 & 21 & 0 & 21 \\
\hline Bacitracin (10 IU) & 0 & 0 & 0 & 0 & 0 & 0 & 0 & 0 \\
\hline Cephalothin (30ug) & 22 & 22 & 23 & 20 & 20 & 29 & 23 & 23 \\
\hline Chloramphenicol (30uj) & 30 & 30 & 30 & 30 & 22 & 29 & 30 & 25 \\
\hline Gentamycin (120ug) & 26 & 24 & 22 & 21 & 20 & 25 & 27 & 24 \\
\hline Nalidixic acid (30ug) & 0 & 0 & 0 & 0 & 0 & 0 & 0 & 0 \\
\hline Penicillin (10IU) & 12 & 13 & 12 & 10 & 9 & 0 & 0 & 7 \\
\hline Polymycin B (300 IU) & 16 & 16 & 16 & 15 & 16 & 16 & 16 & 17 \\
\hline Streptomycin (10ug) & 16 & 16 & 17 & 19 & 21 & 7 & 9 & 0 \\
\hline Tetracyclenes (21ug) & 21 & 20 & 20 & 24 & 20 & 0 & 0 & 0 \\
\hline Vancomycin (30ug) & 0 & 0 & 0 & 0 & 0 & 0 & 0 & 0 \\
\hline
\end{tabular}

Control were $=$ Blank disk $($ Sterilized $)=0 \mathrm{~mm}, \mathrm{fp}=$ food poisoning/Outbreak

Diameter of antimicrobial activity zone measured in $\mathrm{mm}$ after $24 \mathrm{~h}$ incubation period at $37^{\circ} \mathrm{C}$ in duplicates, $\mathrm{n}=2$

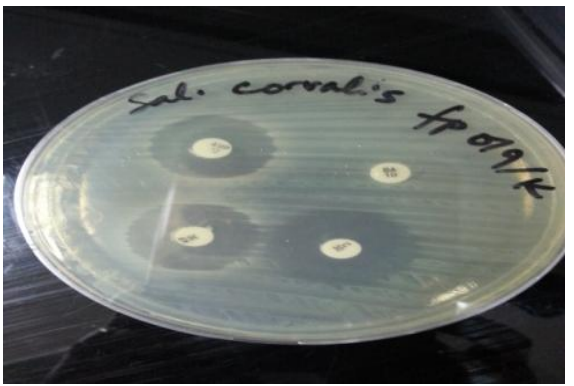

Figure 1: Antibiotic susceptibility of $S$. corvalis against selected antibiotics using DDT method

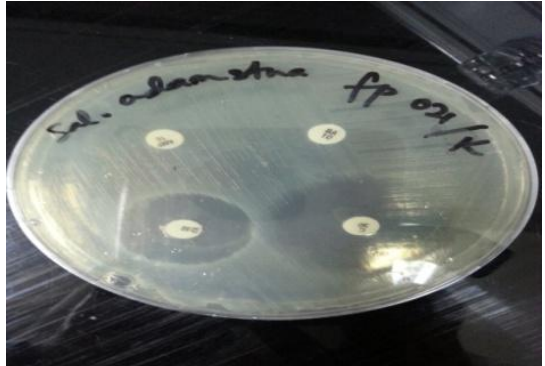

Figure 2: Antibiotic susceptibility of S.adamstua

3.2 Antimicrobial activity of LAB isolated from fermented durian flesh against Multiple Antibiotic Resistant (MAR) of Salmonella strains associated with food poisoning cases in Malaysia

Malaysian fermented durian flesh has been reported to have antimicrobial activity against microorganisms (Issa, 2000, Leisner et al., 2001). However, limited study has been focusing on evaluating the antimicrobial activity of LAB isolated from fermented durian flesh against Salmonella food poisoning strains. Salmonellosis which caused by Salmonella strains showed significant effect to human health and death, where 
the most significant sources of foodborne gastroenteritis world-wide came from Salmonella (Nillian, 2011). The main factors that contribute to Salmonella pathogenesis are its capability to attack epithelial cells and affect the cellular destruction (Abdel-Daim et al., 2013).

In Malaysia, S. enteritidis (28.1\%), S. weltevreden (25.7\%), S. corvallis (10.3\%) and S. typhimurium (6.7\%) were the most common non-typhoidal Salmonella reported for the period 2003 - 2005 (National Public Health Laboratory, 2005). In some regions, S. weltevreden, S. anatum and S. derby have important to be of superior (Bangtrakulnonth et al., 2004). It has been proved that $S$. enterica are common food-borne bacterial pathogens and they are most widespread in chicken, eggs and beef (Lim et al., 2005; Mare et al., 2001; Ray et al., 2007).

All Salmonella strains used in this study showed resistant to bacitracin, nalidixic acid and vancomycin (Table 1). People who suffer from infection related to Salmonella food poisoning were commonly treated by antibiotics by medical practitioners. Nevertheless, this study has confirmed that these three antibiotics; bacitracin, nalidixic acid and vancomycin were not suitable to inhibit the growth of Salmonella. Finding alternative treatment to inhibit these MAR's Salmonella strains is crucial for medicinal purposes. Interestingly, this study demonstrated that several isolates of LAB strains, namely as Lactobacillus plantarum (V1), Lactobacillus buchneri (V9) and Lactobacillus brevis (V11) had strong antimicrobial activity against MAR's Salmonella strains associated with food poisoning cases in Malaysia as shown in Table 2.

Table 2: Antimicrobial activity of crude bacteriocins from cell free supernatant (CFS) of LAB strains against various types of Salmonella spp. from food poisoning isolates using well diffusion method

\begin{tabular}{|c|c|c|c|c|c|c|c|c|c|c|}
\hline & ID & Source & V1 & V3 & v7 & V8 & v9 & V11 & V13 & V14 \\
\hline \multicolumn{11}{|l|}{ Targeted } \\
\hline \multicolumn{11}{|l|}{ Salmonella strains } \\
\hline (ATCC and various serotypes) & & (Water and food contamination ) & \multicolumn{8}{|c|}{ Diameter of inhibition growth $(\mathrm{mm})$} \\
\hline S. typhimurium & ATCC 14028 & American type culture collection & 18 & 18 & 17 & 18 & 20 & 20 & 19 & 20 \\
\hline S. typhimurium & FP 001/K & raw chicken & 18 & 19 & 18 & 17 & 20 & 20 & 21 & 19 \\
\hline S. enteritidis & FP 002/K & water & 18 & 16 & 18 & 14 & 16 & 18 & 18 & 20 \\
\hline S. paratyphi B & FP $003 / \mathrm{K}$ & water & 18 & 12 & 16 & 11 & 15 & 13 & 12 & 14 \\
\hline S. chester & FP 004/K & water & 14 & 10 & 12 & 12 & 18 & 13 & 12 & 14 \\
\hline S. sarajane & FP 006/K & water & 13 & 12 & 12 & 11 & 16 & 15 & 14 & 15 \\
\hline S. richmond & FP 006/K & water & 14 & 9 & 12 & 13 & 18 & 15 & 17 & 18 \\
\hline S. chingola & FP $007 / K$ & water & 13 & 11 & 11 & 9 & 19 & 12 & 12 & 15 \\
\hline S. paratyphi A & FP 008/K & water & 16 & 10 & 12 & 12 & 17 & 15 & 13 & 15 \\
\hline S. louga & FP 009/K & water & 11 & 7 & 12 & 12 & 18 & 15 & 15 & 16 \\
\hline S.mountpleasant & FP 010/K & water & 14 & 12 & 6 & 10 & 17 & 14 & 13 & 14 \\
\hline S. sandiago & FP 011/K & water & 18 & 15 & 17 & 16 & 18 & 16 & 21 & 21 \\
\hline S.winslow & FP 012/K & water & 17 & 16 & 15 & 16 & 19 & 17 & 16 & 17 \\
\hline S. borbeck & FP 013/K & water & 15 & 13 & 13 & 13 & 17 & 15 & 17 & 18 \\
\hline S. rhydyfellin & FP 014/K & coconut milk seive & 17 & 16 & 16 & 17 & 18 & 16 & 17 & 18 \\
\hline S. weltevreden & FP 015/K & water & 20 & 19 & 17 & 21 & 21 & 22 & 22 & 22 \\
\hline S. bareilly & FP 016/K & water & 20 & 19 & 18 & 20 & 20 & 20 & 21 & 20 \\
\hline S. panama & FP $017 / K$ & water & 21 & 17 & 21 & 17 & 20 & 18 & 20 & 21 \\
\hline S. farsta & FP $018 / \mathrm{K}$ & chicken dish & 20 & 21 & 20 & 19 & 19 & 19 & 17 & 19 \\
\hline S. corvalis & FP 019/K & raw chicken & 20 & 18 & 18 & 17 & 21 & 20 & 20 & 20 \\
\hline S. albany & FP 020/K & water & 19 & 17 & 16 & 14 & 18 & 17 & 17 & 18 \\
\hline S.adamstua & FP 021/K & water & 18 & 18 & 18 & 17 & 19 & 18 & 18 & 18 \\
\hline S.tsevie & FP $022 / K$ & water & 14 & 16 & 14 & 15 & 20 & 16 & 17 & 18 \\
\hline S. corvalis & FP 001/T & raw chicken & 20 & 20 & 20 & 20 & 18 & 20 & 18 & 22 \\
\hline S. livingston & $\mathrm{FP} \mathrm{002/T}$ & egg shell & 20 & 20 & 20 & 20 & 20 & 22 & 20 & 22 \\
\hline
\end{tabular}

Control of each plates $=0 \mathrm{~mm}, \mathrm{Fp}=$ food poisoning

Mean diameter of antimicrobial activity zone measured in $\mathrm{mm}$ after $24 \mathrm{~h}$ incubation period at $37^{\circ} \mathrm{C}$

Previously, Oh et al. (2000) reported that crude bacteriocin from Lb. acidophilus 30SC were not capable to inhibit the growth of Gram negative bacteria, including Klebsiella pneumoniae, E. coli and $S$. typhimurium. However, in this study, all four strains of LAB tested namely as Lb. plantarum, Lb. buchneri, Lb. brevis 1 and $L b$. acidophilus 1 were highly capable to inhibit numerous kind of Gram negative bacteria of Salmonella spp. as shown in Table 2. These four strains of LAB are potential strains to be used to fight food poisoning cases in Malaysia since those targeted pathogens were purely isolated from food poisoning cases happened in Malaysia from different sources, including various kinds of water sources and meal dishes (chicken meals). 
Earlier reports showed that isolate of $L b$. pentosus G004 had very strong activity against all the tested bacteria except for S. typhimurium and Bacillus subtilis, which the isolate only had a moderate inhibition activity (Muhialdin et al., 2012). The present finding highlights the potential LAB strains from the Malaysian fermented durian flesh to inhibit Salmonella strains that associated with food poisoning cases in Malaysia. Although the exact mechanism for this antimicrobial activity was not further elucidated, it is well established that cell free supernatant of LAB consists of inhibitory compounds, such as organic acids, oxygen catabolites, proteinaceous compounds, fat and amino acids metabolites and other compounds (Helander eat al., 1977, Valerio et al., 2004). Figure 3 (A-F) exhibits the antimicrobial activity of crude bacteriocin of eight LAB against Salmonella spp. (food poisoning isolates).

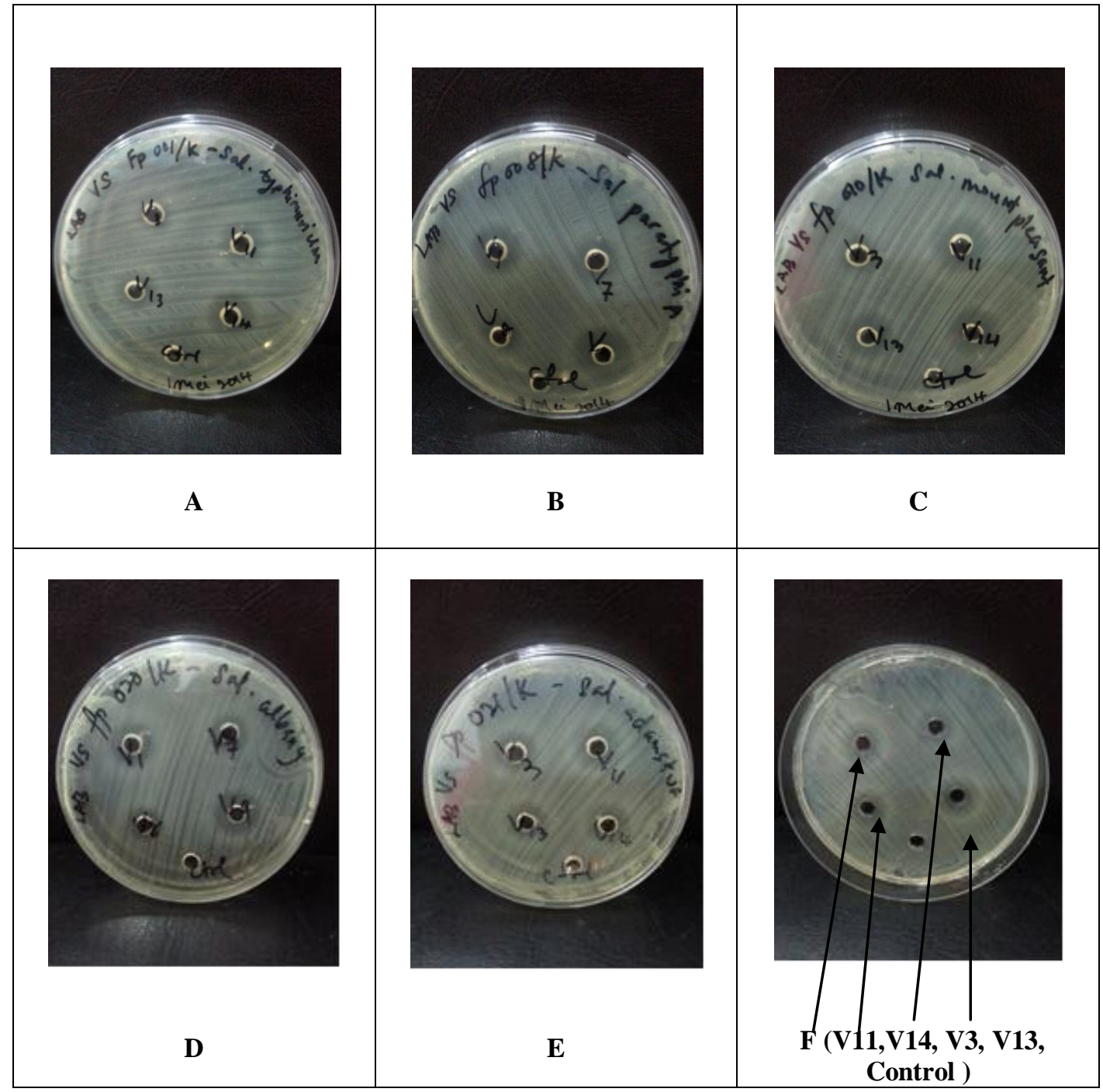

Figure 3 ( $\mathbf{A}-\mathbf{F}$ ): Some pictures of antimicrobial activity of crude bacteriocin of eight LAB against Salmonella spp. (food poisoning isolates): A- S. typhimurium, B- S. paratyphi A, C- S. mountpleasant, $\mathrm{D}-\mathrm{S}$. albany, E - S. adamstua and $\mathrm{F}-\mathrm{S}$. corvalis by well diffusion method

\section{Conclusion}

Eight isolates of Lactic Acid Bacteria strains namely as Lb. plantarum, Lb. acidophilus 1, Lb. brevis and $L b$. buchneri had proven to inhibit abundant serotypes of MAR's Salmonella food poisoning strains from Malaysia. All eight LAB strains showed strong antimicrobial activity with broad spectrum (18-20 mm) diameter inhibition against $S$. typhimurium ATCC 14028. Besides that, cell free supernatant of eight LAB isolates (V1, V3, V7, V8, V9, V11, V13 and V14) showed strong antimicrobial activity against other 23 serotypes of MAR's Salmonella associated with food poisoning cases in Malaysia with almost $100 \%$ broad spectrum antimicrobial activities. This finding highlights the potential of fermented durian flesh to be used as bio-preservative substance in providing the solution in reducing the food poisoning and foodborne diseases cases in Malaysia and 
all over the world. Further investigation will be done to understand the mechanism of related bacteriocins from these $\mathrm{LAB}$ strains in controlling the cycle of food poisoning incidences.

\section{Acknowledgements}

The first author would like to thank Food Safety and Quality Division, Ministry of Health, Malaysia for giving permission of using laboratory facilities and Training Division, Ministry of Health, Malaysia for providing scholarship. Authors thank to Ministry of Education, Malaysia for providing financial support to carry out this project through Fundamental Research Grant Scheme (FRGS), Vot. No. 59269. Special thank to Nik Mohd Hafiz for giving some technical advice related to this study. The authors also would like to acknowledge the use of facilities in Food Safety and Quality Control Laboratory, Terengganu Health Department, Horseshoe Crab Laboratory, and Food Microbiology Laboratory, UMT.

\section{References}

[1]. Abdel-Daim, A., Hassouna, N., Hafez, M., Ashor, M. S. A., \& Aboulwafa, M. M. (2013). Antagonistic activity of Lactobacillus isolates against Salmonella typhi in vitro. BioMed Research International, 2013, 680605. doi:10.1155/2013/680605

[2]. Archambault M, Petrov P, Hendriksen RS, Asseva G, Bangtrakulnonth A, Hasman H, Aarestrup FM (2006). Molecular characterization and occurrence of extended-spectrum B-lactamase resistance genes among Salmonella enterica serovar corvallis from Thailand, Bulgaria,and Denmark. Microb. Drug Resist., 12: 192-198.

[3]. Aween, M.M., Hassan, Z., Muhialdin, B.J., Eljamel, Y.A., Al-Mabrok, A.S.W. and Lani, M.N. (2012) Antibacterial Activity of Lactobacillus acidophilus Strains Isolated from Honey Marketed in Malaysia against Selected Multiple Antibiotic Resistant (MAR) Gram-Positive Bacteria. Journal of Food Science, 77(7), M364-M371.

[4]. Battcock, M., \& Ali, S.A. (1998). Fermented fruits and vegetables, a global perspective FAO Agricultural Services Bulletin No 134, Rome, Italy.

[5]. Bouchrif B, Paglietti B, Murgia M, Piana A, Cohen N, Ennaj MM, Rubino S, Timinoun M (2009). Prevalence and antibioticresistance of Salmonella isolated from food in Morocco. J. Infect. Dev. Countries, 3(1): 35-40.

[6]. Ekowati, C.N. (1998). Mikroflora pada fermentasi daging buah durian (tempoyak). Jurnal Sains dan Teknologi Edisi Khusus, 136141.

[7]. Helander, I. M. , A. von Wright, and T.-M. Mattila-Sandholm (1997) "Potential of lactic acid bacteria and novel antimicrobials against Gram-negative bacteria," Trends in Food Science and Technology, vol.8, no. 5, pp.146-150.

[8]. Irwandi \& Che-Man, Y.B. (1996). Durian leather: development, properties and storage stability. Journal of Food Quality, 19: 439489.

[9]. Issa, Z. M. (2000). Molecular characterization of Lactobacillus plantarum isolated from Malaysian fermented foods. [MS Thesis]. Universiti Putra Malaysia.

[10]. Kormin, S., Rusul, G., Radu, S. and Ling, F. H. (2001). Bacteriocin-producing Lactic Acid Bacteria isolated from traditional fermented food. Malaysian Journal of Medical Sciences. 8(1), 63-68.

[11]. Leisner, J.J., Vancanneyt, M., Rusul, G., Pot, B., Lefebvre, K., Fresi, A., \& Tee, L.K. (2001). Identification of lactic acid bacteria constituting the predominating microflora in an acid-fermented condiment (tempoyak) popular in Malaysia. International Journal of Food Microbiology, 63(1-2): 149-157.

[12]. Lim H, Lee KH, Hong CH, Bahak GJ, Choi WS (2005). Comparison of four molecular typing methods for the differentiation of Salmonella spp. International Journal of Food Microbiology, 105: 411-418.

[13]. Oh, S., Kim, S.H., \& Worobo, R.W. (2000). Characterisation and purification of a bacteriocins produced by a potential probiotic culture, Lactobacillus acidophilus 30SC. Journal of Dairy Science, 83:2747-2752.

[14]. Mare L, Dicks LMT, Walt ML (2001). Characterization of South African isolates of Salmonella enteritidis by phage typing, numerical analysis of RAPD-PCR banding patterns and plasmid profiles. International Journal of Food Microbiology, 64: 237-245.

[15]. Modarressi, S., \& Thong, K. L. (2010). Isolation and molecular sub typing of Salmonella enterica from chicken, beef and street foods in Malaysia. Scientific Research and Essays. 5(18), 2713-2720.

[16]. Muhialdin, B. J., Hassan, Z., Ahmed Imdakim, M. M., Abdul Kahar, F. K. S., \& Aween, M. M. (2012). Malaysian isolates of lactic acid bacteria with antibacterial activity against Gram-positive and Gram-negative pathogenic bacteria. Journal of Food Research, 1(1): 110-116.

[17]. National Public Health Laboratory Malaysia (2005). Surveillance. http://www.dph.gov.my/mkak/report/surveillancereport.htm>.

[18]. Nillian, E. (2011). Simultaneous Detection of Salmonella spp., Salmonella enteritidis and Salmonella typhimurium in Raw Salad Vegetables and Vegetarian Burger Patties. Food and Nutrition Sciences, 02(10), 1077-1081. doi:10.4236/fns.2011.210144

[19]. Popoff MY (2001). Antigenic formulas of the Salmonella serovars, $8^{\text {th }}$ revision. WHO Collaborating Centre for Reference and Research on Salmonella, Institute Pasteur, Paris.

[20]. Ray KA, Warnick LD, Mitchell RM, Kaneene JB, Ruegg PL, Wells SJ, Fossler CP, Halbert LW, May K (2007). Prevalence of antimicrobial resistance among Salmonella on midwest and northeast USA dairy farms. Prev. Vet. Med., 79: $204-223$.

[21]. Salleh, F., Lani, M.N., Ismail, N., Aween, M.M. \& Alias, R. (2014). Identification of Lactic Acid Bacteria Species Isolated from Fermented Durian Flesh (Tempoyak) in Kuala Terengganu and Marang Markets and Their Antimicrobial Activities Against Selected Pathogenic Bacteria. Proceedings of the International Conference on Beneficial Microbes ICOBM, 214-218

[22]. Valerio, F., Lavermicocca, P., Pascale, M. and Visconti, A. (2004) "Production of phenyllactic acid by lactic acid bacteria: an approach to the selection of strains contributing to food quality and preservation," FEMS Microbiology Letters, vol.233, no. 2, pp. 289-295.

[23]. Vlková, E., Rada, V., Popelářová, P., Trojanová, I. \& Killer, J. (2006). Antimicrobial susceptibility of Bifidobacteria isolated from gastrointestinal tract of calves. Livestock Science, 105: 253-259.

[24]. Wirawati, C.U. (2002). Potensi bakeri asam laktat yang diisolasi dari tempoyak sebagai probiotic. M. Sc. Thesis. Bogor: Institut Pertanian Bogor, Indonesia.

[25]. Yuliana, N. \& Dizon, E.I. (2011). Phenotypic identification of lactic acid bacteria isolated from Tempoyak (fermented durian) made in the Philippines. International Journal of Biology, Vol. 3 (2): 145-152. 